\title{
ŻYCIE Z PSAMI W MIEŚCIE
}

Zarys treści: Celem artykułu jest wskazanie na wybrane przestrzenne konsekwencje posiadania psów w mieście. Diagnoza obejmuje zarówno elementy przestrzeni realnej, jak i dotyczy społecznej percepcji zjawiska posiadania i życia psów w mieście. Przestrzeń została powiązana z przestrzenią publiczną, rekreacją i wypoczynkiem. Studium przypadku stanowi Łódź. Badania prowadzono od roku 2013 do 2017.

Słowa kluczowe: Przestrzeń miasta, psy, posiadacze psów, użytkowanie przestrzeni publicznych, samorząd.

\section{Wprowadzenie}

Miasto, ze swej definicji, to przestrzeń zawłaszczona przez kulturę, środowisko sztuczne, antropogeniczne, miejsce zamieszkania ludzi. Człowiek jednak od wielu tysięcy lat otacza się zwierzętami. Domestykacja nastąpiła już w epoce kamiennej (Lorenz 2013). W Europie ślady archeologiczne wskazują na ok. 17000 lat wstecz (Veriginelli et al. 2005). Pierwszym udomowionym zwierzęciem był pies. Jak pisze K. Lorenz (2013) w swojej słynnej książce I tak człowiek trafit na psa, sposoby jego udomawiania różniły się w różnych częściach ekumeny. Pies i kolejne oswojone stworzenia stały się dla ludzi narzędziami pracy, pożywieniem, a nawet częścią kultów religijnych. Hodowla była i jest domeną wsi. Jednak zwierzęta zamieszkały z ludźmi również w miastach.

Liczby są znamienne. W USA liczba gospodarstw domowych z psami przewyższa liczbę gospodarstw domowych z dziećmi. W 2016 roku było tam ponad $60 \mathrm{mln}$ (liczbę psów szacuje się na $70 \mathrm{mln}$ ) gospodarstw posiadających psa. Wartość rynku produktów związanych z utrzymaniem domowych pupili szacowano w 2017 roku na ok. 70 mld USD. Oznacza to prawie 60 pp. wzrostu przez ostatnie 10 lat. Przeciętny właściciel psa oceniał swoje roczne wydatki na ok. 1600 USD. Największa ich część przeznaczana była na opiekę weterynaryjną i hotele dla zwierząt. Warto wspomnieć także o stale powiększającym się rynku ubezpieczeń dla zwierząt ${ }^{1}$.

\footnotetext{
${ }^{1}$ Pet Industry Market Size \& Ownership Statistics, American Pet Products Association, http://www.americanpetproducts.org/press_industrytrends.asp.
} 
W Polsce sytuacja wygląda podobnie. Jak podaje GUS ${ }^{2}$ w 2016 roku liczba dzieci (wiek 0-17 lat) w naszym kraju wynosiła $6,8 \mathrm{mln}$. W tym samym czasie liczbę psów szacowano na $7,1 \mathrm{mln}^{3}$. Obserwuje się stały wzrost rynku karm dla psów - ok. 6\% rok do roku w ciągu ostatnich lat. W 2017 roku wartość tego rynku oceniano na 1,3 mld PLN ${ }^{4}$. Dla psów kupuje się jednak nie tylko karmę. W ofercie są m.in. zabawki, artykuły pielęgnacyjne, kojce, budy, sprzęt do tresury, akcesoria samochodowe, specjalna odzież dla właścicieli. Pieniądze wydaje się także na usługi. Do niech zaliczyć można wspomnianą wyżej opiekę weterynaryjną, pielęgnację, tresurę, opiekę hotelową etc.

Oprócz znaczenia dla gospodarki posiadanie psów ma inne konsekwencje. Przede wszystkim można tu wskazać na ich rolę społeczną. Psy i inne zwierzęta domowe stały się „,złonkami rodziny” i „najlepszymi przyjaciółmi”. Można zaryzykować tezę, że są, w niektórych przypadkach, substytutem partnerów lub dzieci - przynajmniej część właścicieli tak je traktuje (por. Konecki 2005). Wydaje się, że to one stanowią element prewencji w zachowaniu normalnych relacji społecznych czy wręcz pozostaniu przy życiu (por. Szacki 1964; Durkheim 2011). W społeczny wymiar posiadania psów wpisuje się na pewno także pojęcie rekreacji i czasu wolnego. Spacery, zabawy, wystawy, sport i treningi (np. agility ${ }^{5}$ ) to tylko niektóre sposoby spędzana czasu z pupilem.

Niezależnie od tego czy mówimy o aspektach ekonomicznych, czy o aspektach społecznych posiadania psów, życie z psami ma postać przestrzenną. To oraz znaczenie gospodarcze i społeczne, powinno być wystarczającą przesłanką dla geografów do zajęcia się problematyką psów. Miasto wydaje się być szczególnym przypadkiem. Wszelkie interakcje zarówno pozytywne, jak i negatywne zachodzą tutaj na małej przestrzeni, która ze swej definicji jest przestrzenią kultury, a nie natury, ludzi, a nie zwierząt. Może powodować to wiele konfliktów. Propozycje ich rozwiązania to także potencjalne zadanie dla geografów.

Celem artykułu jest wskazanie na wybrane przestrzenne konsekwencje posiadania psów w mieście. Diagnoza obejmuje zarówno elementy przestrzeni realnej, jak i dotyczy społecznej percepcji zjawiska posiadania i życia psów w mieście. To co przestrzenne zostało przede wszystkim powiązane z przestrzenią publiczną, rekreacją i wypoczynkiem. Studium przypadku stanowi Łódź. Badania prowadzo-

${ }^{2}$ Stan i struktura ludności wedtug wieku w latach 1989-2016, stan na 31.12.2016, GUS, http://stat.gov.pl/obszary-tematyczne/ludnosc/ludnosc/struktura-ludnosci,16,1.html.

${ }^{3}$ Number of dogs in the European Union in 2016, Statista The Statistics Portal, https:// www.statista.com/statistics/414956/dog-population-european-union-eu-by-country/.

${ }^{4}$ Dog food in Poland, 2017, Euromonitor International, http://www.euromonitor.com/ dog-food-in-poland/report.

${ }^{5}$ Rodzaj sportu, polegający na przebyciu przez psa i jego opiekuna specjalnego toru przeszkód. 
no od roku $2013^{6}$ do 2017. Wykonano inwentaryzację wybranych terenów zieleni w Łodzi i wywiady eksperckie z przedstawicielami Straży Miejskiej w Łodzi oraz Oddziału ds. ekonomicznych i kontrolnych Wydziału Gospodarki Komunalnej w Łodzi. Dodatkowo przeanalizowano dane pozyskane $\mathrm{z}$ instytucji, takich jak: Straż Miejska w Łodzi, Powiatowy Inspektorat Weterynarii (PIW) w Łodzi oraz Bank Danych Lokalnych Głównego Urzędu Statystycznego. Skoncentrowano się na sytuacji bieżącej, co w praktyce oznacza okres ostatnich pięciu lat.

\section{Diagnoza - liczba psów i konsekwencje interakcji z mieszkańcami miasta - perspektywa władz samorządowych}

Liczbę psów w Łodzi da się ustalić jedynie szacunkowo. Po pierwsze można odwołać się do zapisu prawa. Zgodnie z art. 56 pkt. 2 Ustawy o ochronie zdrowia zwierząt oraz zwalczaniu chorób zakaźnych zwierząt „posiadacze psów są obowiązani zaszczepić psy przeciwko wściekliźnie w terminie 30 dni od dnia ukończenia przez psa 3 miesiąca życia, a następnie nie rzadziej niż co 12 miesięcy od dnia ostatniego szczepienia". Niestety, znaczna liczba właścicieli psów nie przestrzega tego przepisu. Zatem dane udostępnione przez PIW nie są w pełni miarodajne. Wynika z nich, że w latach $2006-2016^{7}$ na terenie miasta szczepionych było ok. 15 tys. psów (ryc. 1).

Szacunki ekspertów Urzędu Miasta w Łodzi są zgoła inne. Podają oni, że liczba psów w mieście waha się między 70 a 80 tys. Ostatnie rzetelne badania pochodzą jednak z 2003 roku. Brak wiedzy o liczbie zwierząt jest oczywiście konsekwencję braku obowiązku rejestracji.

Warto zwrócić uwagę, że od 2008 roku nie płaci się podatku od posiadania psów. Obowiązujące od tego roku przepisy zmieniły podatek w opłatę i pozostawiły ją w gestii samorządów - opłata, inaczej niż podatek, nie jest obligatoryjna (Szkwarek 2016). W Łodzi kolejne próby przywrócenia ${ }^{8}$ opłaty są odrzucane przez Radę Miasta. Zakładając jednak, że wysokość opłaty wynosiłaby 50 zł - takie były ostatnie propozycje Prezydent Łodzi, a jego ściągalność sięgnęłaby 80\%, to przychód miasta mógłby wynieść nawet $3 \mathrm{mln}$ zł.

Choć brakuje przychodów z tytułu posiadania psów, samorządowcy podejmują różnorodne działania mające na celu ułatwienie funkcjonowania zwierząt

${ }^{6} \mathrm{~W} 2013$ roku badania ankietowe prowadzone były przez studentów Wydziału Nauk Geograficznych Uniwersytetu Łódzkiego. Badania uzupełniono w 2015 roku w ramach projektu indywidualnego w Katedrze Geodezji, Kartografii Środowiska i Geometrii Wykreślnej Politechniki Łódzkiej.

${ }^{7}$ Dane statystyczne Powiatowego Inspektoratu Weterynaryjnego w Łodzi dotyczące liczby zaszczepionych psów przeciwko wściekliźnie.

${ }^{8}$ Jest to możliwe na podstawie Ustawy z dnia 12 stycznia 1991 roku o podatkach i optatach lokalnych (Dz.U., 2006, 121.844). 


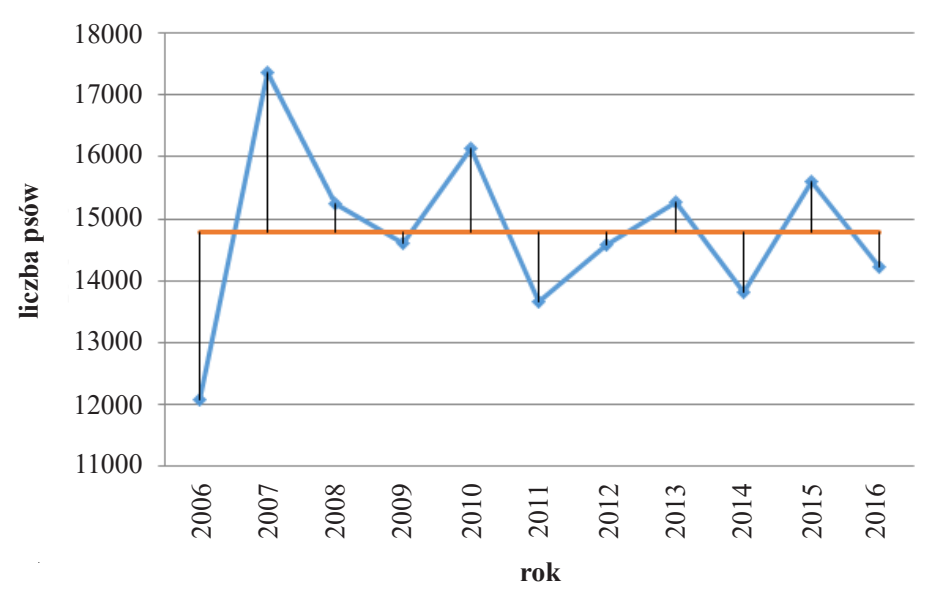

Ryc. 1. Liczba zaszczepionych psów przeciwko wściekliźnie w latach 2006-2016 na terenie miasta Łodzi

Źródło: opracowanie własne na podstawie danych udostępnionych przez Państwowy Inspektorat Weterynaryjny w Łodzi

w mieście i ograniczenie konfliktów z tym związanych. Działania te dotyczą nie tylko psów, a zwierząt w ogóle, w tym w części zwierząt bezdomnych. W znacznej części wynikają one z obowiązujących w Polsce przepisów prawnych - ustaw samorządowych i innych branżowych. Do najważniejszych branżowych zaliczyć można: Ustawę z dnia 13 września 1996 roku o utrzymaniu czystości i porządku w gminach ${ }^{9}$ oraz Ustawe z dnia 21 sierpnia 1997 roku o ochronie zwierzat ${ }^{10}$, Ustawe z dnia 11 marca 2004 roku o ochronie zdrowia zwierząt oraz zwalczaniu chorób zakaźnych zwierząt ${ }^{11}$ i Rozporządzenie Ministra Spraw Wewnętrznych i Administracji z dnia 26 sierpnia 1998 roku w sprawie zasad $i$ warunków wyłapywania bezdomnych zwierząt ${ }^{12}$. Rozwiązania dotyczące zwierząt bezdomnych $\mathrm{w}$ Łodzi opisane zostały w uchwałach Rady Miasta. Corocznie przyjmuje się np. „Program opieki nad zwierzętami bezdomnymi oraz zapobieganiu bezdomności zwierząt w Łodzi”. Ostatni obowiązuje od marca 2017 roku. Zakłada on ${ }^{13}$ m.in.:

1. Zapewnienie bezdomnym zwierzętom miejsca w Schronisku dla Zwierząt z siedzibą w Łodzi (ul. Marmurowa 4);

2. Opiekę nad wolno żyjącymi kotami, w tym ich dokarmianie w sezonie zimowym;

${ }^{9}$ Dz.U., 1996, nr 132, poz. 622.

${ }^{10}$ Dz.U., 2003, nr 106, poz. 1002, z późn. zm.

${ }^{11}$ Dz.U., 2008, nr 213, poz. 1342, z późn. zm.

${ }^{12}$ Dz.U., 1998, nr 116, poz. 753, z późn. zm.

${ }^{13}$ Uchwała nr XLIII/1154/17 Rady Miejskiej w Łodzi z dnia 15 marca 2017 roku w sprawie przyjęcia „Programu opieki nad zwierzętami bezdomnymi oraz zapobiegania bezdomności zwierząt w Łodzi na rok 2017’. 
3. Odławianie bezdomnych zwierząt;

4. Plan sterylizacji lub kastracji zwierząt, zapewniający właścicielom zwierząt lub innym osobom, pod których opieką zwierzęta pozostają finansowanie $50 \%$ kosztów zabiegów sterylizacji i kastracji psów i kotów utrzymywanych na terenie Miasta Łodzi;

5. Obligatoryjną sterylizację lub kastrację zwierząt w Schronisku dla Zwierząt z siedzibą w Łodzi;

6. Poszukiwanie właścicieli dla bezdomnych zwierząt;

7. Usypianie ślepych miotów;

8. Wskazanie gospodarstwa rolnego w celu zapewnienia miejsca dla zwierząt gospodarskich;

9. Zapewnienie całodobowej opieki weterynaryjnej w przypadkach zdarzeń drogowych z udziałem zwierząt;

10. Plan znakowania zwierząt, obejmujący znakowanie psów utrzymywanych na terenie miasta Łodzi oraz kotów posiadających właściciela;

11. Wskazanie wysokości środków finansowych przeznaczonych na jego realizację oraz sposób wydatkowania tych środków;

12. Prowadzenie przez Straż Miejską w Łodzi i inne podmioty lub organizacje działań edukacyjnych i informacyjnych mających na celu promowanie właściwych postaw i zachowań w stosunku do zwierząt.

Podstawowym aktem prawnym regulującym utrzymanie zwierząt domowych na terenie miasta Łodzi jest Uchwała Nr XXXI/808/16 Rady Miejskiej w Łodzi z dnia 15 czerwca 2016 roku w sprawie wprowadzenia Regulaminu utrzymania czystości i porządku na terenie miasta Łodzi ${ }^{14}$. Regulamin określa obowiązki osób utrzymujących zwierzęta domowe oraz wymagania w zakresie utrzymywania zwierząt gospodarskich. Właściciele psów mają obowiązek:

1. Utrzymywać stałą i skuteczną kontrolę nad zwierzętami, wyjątek stanowi sytuacja kiedy zwierzęta pozostają na terenie ogrodzonym;

2. Utrzymywać psy na uwięzi podczas spacerów w miejscach publicznych;

3. Utrzymywać psy agresywne wszystkich ras wymienionych w Rozporządzeniu Ministra Spraw Wewnętrznych i Administracji z dnia 28 kwietnia 2003 roku w sprawie wykazu psów uznawanych za agresywne (Dz.U., nr 77, poz. 687) oraz mieszańców tych ras na uwięzi w założonych kagańcach;

4. Podczas spacerów, gdy nie stwarza to zagrożenia dla innych osób, dopuszcza się spuszczenie z uwięzi psa w założonym kagańcu pod stałą kontrolą właściciela i niezwłoczne założenie uwięzi psu na wezwania funkcjonariusza Straży Miejskiej;

${ }^{14}$ Uchwała Nr XXXI/808/16 Rady Miejskiej w Łodzi z dnia 15 czerwca 2016 roku w sprawie wprowadzenia Regulaminu utrzymania czystości i porządku na terenie miasta Łodzi (Rozdział 5 § 19.2). 
5. Niezwłoczne usuwanie odchodów zwierząt z terenów publicznych oraz z nieruchomości użytku publicznego i gromadzenie tych zanieczyszczeń w specjalnie oznakowanych koszach lub zwykłych koszach ulicznych wyłożonych workami z tworzyw sztucznych;

6. Posiadania worków, torebek lub urządzeń do zbierania odchodów.

Jednostką odpowiedzialną za realizację ww. uchwał na terenie miasta jest Wydział Gospodarki Komunalnej w Łodzi. Jest to komórka organizacyjna Departamentu Spraw Społecznych. Jak wynika z rozmów z ekspertami, największym problemem w mieście jest utrzymanie czystości. Szacuje się, że łódzkie psy zostawiają dziennie ok. 20 ton odchodów. Niestety, prowadzony od 2003 roku program „Posprzątaj! To nie jest kupa roboty”, nie przynosi oczekiwanych skutków. Trzeba dodać, że choć program kojarzony jest przez łodzian głównie z akcją promocyjną, to podjęte zostały także działania „twarde”. Powstały „psie toalety” - wydzielone miejsca dla psów. W mieście rozstawiono specjalnie oznakowane pomarańczowe kosze do gromadzenia psich odchodów. Dla mieszkańców miasta są dostępne bezpłatne torebki do zbierania nieczystości po psach. Niestety, niedługo po wprowadzeniu tych udogodnień, ,psie stacje” i „psie toalety” zostały w większości zniszczone. Obecnie pozostały tylko specjalne pomarańczowe kosze.

Z myślą o psach został stworzony także program „Wzorcowy Właściciel Psa”, którego celem było uświadamianie społeczeństwa o tym, jakie obowiązki niesie ze sobą posiadanie czworonoga. Kolejną inicjatywą miasta było utworzenie w 2005 roku pierwszego w Polsce „psiego parku” przy ul. Liściastej. Niestety, zaraz po otwarciu, już drugiego dnia okazało się, że park został zdewastowany przez chuliganów i obecnie na terenie miasta nie ma specjalnych terenów przeznaczonych dla właścicieli psów. Jak podkreśliła jedna z ekspertek, dewastacja parku przy ul. Liściastej może wskazywać na brak gotowości mieszkańców miasta na rozwój podobnej infrastruktury.

To co jest najbardziej widoczne w przestrzeni miasta, to z pewnością działania Straży Miejskiej egzekwującej obowiązujące przepisy. Dane pozyskane ze Straży Miejskiej w Łodzi dotyczące liczby wystawionych mandatów, pouczeń i notatek w latach 2012-2016 wskazują na systematyczną poprawę. W 2012 roku Straż Miejska interweniowała w sprawach związanych z posiadaniem psów ponad 2,5 tys. razy. W 2016 roku liczba interwencji spadła do 1330 (ryc. 2). Jak komentuje ekspert ze Straży Miejskiej jest to prawdopodobnie efekt wzrostu świadomości właścicieli. Dodać można do tego presję wywołaną na „psiarzy” przez innych łodzian.

W strukturze wykroczeń dominują te związane z utrzymaniem czystości. Nie jest to jednak niesprzątanie po psie, lecz brak torebki na odchody. Brak nadzoru nad zwierzęciem stanowił najmniejszy problem (tab. 1). Najwięcej interwencji podjęto na Bałutach ${ }^{15}$, najmniej na Polesiu. Gdy jednak odnieść działania Straży

${ }^{15}$ Tradycyjnie Łódź podzielona była na pięć jednostek: Bałuty, Polesie, Górną, Śródmieście i Widzew. 


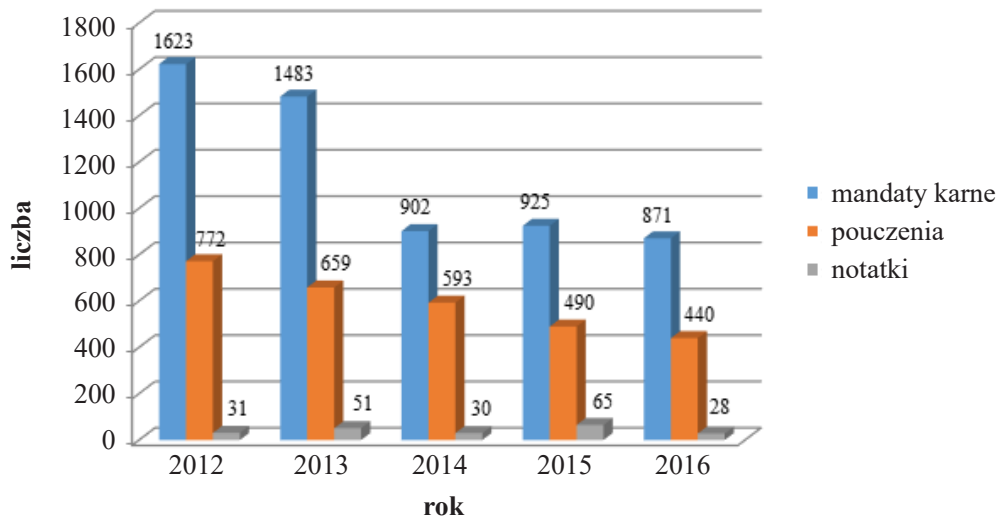

Ryc. 2. Liczba mandatów, pouczeń i notatek wystawionych przez Straż Miejską w Łodzi w latach 2012-2016

Źródło: opracowanie własne na podstawie danych statystycznych ze Straży Miejskiej w Łodzi

Tabela 1. Wykroczenia i podjęte przez Straż Miejską w Łodzi działania w 2016 r.

\begin{tabular}{|c|c|c|c|c|c|c|c|c|}
\hline \multirow{2}{*}{$\begin{array}{c}\text { Wykroczenia/ } \\
\text { działania }\end{array}$} & \multicolumn{5}{|c|}{ Oddziały dzielnicowe } & \multicolumn{2}{|c|}{ Oddziały } & \multirow[b]{2}{*}{ Razem } \\
\hline & Bałuty & Górna & $\begin{array}{l}\text { Śród- } \\
\text { mieście }\end{array}$ & Polesie & Widzew & $\begin{array}{c}\text { Pre- } \\
\text { wencja }\end{array}$ & $\begin{array}{l}\text { Ogólno- } \\
\text { miejski }\end{array}$ & \\
\hline \multicolumn{9}{|c|}{ Brak właściwego nadzoru nad psem } \\
\hline Mandaty karne & 28 & 42 & 7 & 13 & 9 & 31 & 72 & 202 \\
\hline Pouczenia & 25 & 18 & 11 & 13 & 17 & 0 & 0 & 204 \\
\hline Notatki & 1 & 1 & 0 & 0 & 0 & 2 & 1 & 5 \\
\hline \multicolumn{9}{|c|}{ Niesprzątanie psich odchodów, Akcja „Posprzątaj! To nie jest kupa roboty” } \\
\hline Mandaty karne & 48 & 79 & 84 & 18 & 27 & 2 & 7 & 265 \\
\hline Pouczenia & 26 & 25 & 5 & 7 & 8 & 2 & 3 & 76 \\
\hline Notatki & 2 & 3 & 2 & 2 & 1 & 0 & 0 & 10 \\
\hline \multicolumn{9}{|c|}{ Brak torebki lub urządzeń do zbierania psich odchodów } \\
\hline Mandaty karne & 181 & 132 & 47 & 18 & 25 & 0 & 1 & 404 \\
\hline Pouczenia & 98 & 37 & 5 & 4 & 11 & 3 & 2 & 160 \\
\hline Notatki & 12 & 1 & 0 & 0 & 0 & 0 & 0 & 13 \\
\hline \multicolumn{9}{|c|}{ Łącznie } \\
\hline Mandaty karne & 257 & 253 & 138 & 49 & 61 & 33 & 80 & 871 \\
\hline Pouczenia & 149 & 80 & 21 & 24 & 36 & 5 & 5 & 440 \\
\hline Notatki & 15 & 5 & 2 & 2 & 1 & 2 & 1 & 28 \\
\hline
\end{tabular}

Źródło: opracowanie własne na podstawie danych statystycznych Straży Miejskiej w Łodzi 
do liczby mieszkańców okazuje się, że największe ich natężenie było w Śródmieściu, dalej na Bałutach i Górnej - najmniej na Polesiu. Wydaje się, że na podstawie tych wartości wnioskować można raczej o aktywności strażników, nie zaś o liczbie psów bądź niefrasobliwości mieszkańców. Ekspert Straży Miejskiej zwrócił uwagę na wzrost zaniedbań związanych z poczuciem bezkarności - czyli oddaleniem od monitoringu.

\section{Diagnoza - aspekt przestrzenny}

Jak zaznaczono wyżej posiadanie psów w mieście wiąże się ze specyficznym wykorzystaniem przestrzeni publicznych. Gdy połączyć to z rekreacją pojawia się pojęcie przestrzeni rekreacyjnej. M. Drzewiecki pisze: „Przestrzeń rekreacyjna to ta część przestrzeni geograficznej, która ma cechy korzystne dla realizacji różnych form zachowań w czasie wolnym, jak również charakteryzującym się istnieniem procesów rekreacyjnych o rozmiarach istotnych społecznie i przestrzennie" (za: Sławek et al. 2011: 276). Jednym z typów przestrzeni rekreacyjnej są miejskie przestrzenie rekreacyjne (por. Toczek-Werner 2007). W tej kategorii mieszczą się parki zabawy i rozrywki, dokładnie: parki zabawy i rozrywki, parki z kąpieliskami, parki ogrodowe i zooparki, parki gier i sportów (Duricek, Obodyński 2006). Przez właścicieli psów wykorzystywane są, lub mogą być, parki ogrodowe i parki gier i sportów. Dodatkowo psy pojawiają się na skwerach, zieleńcach osiedlowych i po prostu chodnikach.

W Łodzi w skład systemu zieleni miejskiej wchodzą wszystkie z wymienionych typów zieleni. Według danych statystycznych GUS, w roku $2015^{16}$ ogólna powierzchnia terenów zieleni wraz gruntami leśnymi wynosiła 9133,3 ha, co stanowiło ok. $31 \%$ powierzchni geodezyjnej miasta. Parki i zieleńce stanowiły ok. 2,4\% tej powierzchni. Na terenie miasta Łodzi znajduje się 13 zabytkowych parków, które zostały objęte ochroną konserwatorską. Parki te są wpisane do rejestru zabytków nieruchomych województwa łódzkiego ${ }^{17}$. Badaniom inwentaryzacyjnym poddane zostało sześć jednostek. Dobór miał charakter celowy. Przesłanki stanowiły lokalizacja i funkcje parku lub skweru (tab. 2).

Inwentaryzacja wybranych parków została przeprowadzona w czerwcu $2017 \mathrm{r}$. $\mathrm{Na}$ jej podstawie można stwierdzić, że infrastruktura w postaci ławek, latarni i koszy na śmieci oraz czystość terenów rekreacyjnych pozostaje na dobrym poziomie. Wszystkie parki mają regulaminy, lecz w żadnym z nich nie ma przepisów dotyczących właścicieli psów. Nie ma także jasno wyznaczonych obszarów dla psów. Zakazy wejścia dla czworonogów pojawiają się dopiero przed ogrodzonymi placami zabaw i siłowniami miejskimi, które znajdują się w granicach parków.

${ }^{16}$ Statystyka Łodzi 2016, Urząd Statystyczny w Łodzi, http://lodz.stat.gov.pl/publikacje-i-foldery/roczniki-statystyczne/statystyka-lodzi-2016,4,12.html (dostęp: 09.06.2017).

${ }^{17}$ Oficjalna strona Zarządu Zieleni Miejskiej w Łodzi, http://www.zzm.lodz.pl/o-zzm/ parki (dostęp: 22.06.2017). 
Tabela 2. Uzasadnienie wyboru parków i skwerów do przeprowadzenia inwentaryzacji

\begin{tabular}{lll}
\hline Inwentaryzowana jednostka & Dzielnica & \multicolumn{1}{c}{ Podstawy wyboru } \\
\hline Park Piastowski & Bałuty & $\begin{array}{l}\text { Typ parku osiedlowego, prognozowani } \\
\text { użytkownicy: duża liczba właścicieli } \\
\text { psów }\end{array}$ \\
\hline Park Staromiejski & Bałuty & $\begin{array}{l}\text { Lokalizacja przy największym centrum } \\
\text { handlowym i kulturalno-rozrywkowym } \\
\text { w Łodzi }\end{array}$ \\
\hline Park im. H. Sienkiewicza & Sródmieście & \begin{tabular}{l} 
Lokalizacja w centrum miasta \\
\hline Park im. J. Piłsudskiego
\end{tabular} \\
\hline Polesie & $\begin{array}{l}\text { Największy park w Łodzi, popularne } \\
\text { i najbardziej uczęszczane miejsce przez } \\
\text { właścicieli psów }\end{array}$ \\
\hline Park im. W. Reymonta & Górna & $\begin{array}{l}\text { Wysokie walory krajobrazowe (staw) } \\
\text { i estetyczne parku zachęcające właści- } \\
\text { cieli psów do odwiedzania tego miejsca }\end{array}$ \\
\hline Pasaż Abramowskiego & Widzew & $\begin{array}{l}\text { Pasaż osiedlowy zlokalizowany } \\
\text { w gęstej tkance miejskiej }\end{array}$ \\
\hline
\end{tabular}

Źródło: opracowanie własne

Zauważalny jest brak wyposażenia parków w specjalne kosze na odchody. Tylko w Parku Staromiejskim (3 szt.) i Parku Piastowskim (5 szt.) znajdują się takie pojemniki. Brakuje również dyspozytorów na worki na odchody oraz ujęć wody do picia i kąpieli dla psów. W żadnym z badanych miejsc nie było wyznaczonych dla zwierząt miejsc ,do wybiegania”. Infrastruktura do uprawiania sportów z psami jest tym bardziej nieosiągalna. Problemem są także pozostające poza kontrolą właścicieli, spuszone ze smyczy, psy. Stanowią one potencjalne zagrożenie dla innych użytkowników terenów. Często także dewastują zieleń.

Szanse na zmiany pojawiły się na osiedlu Teofilów-Wielkopolska. Rada Osiedla zgłosiła bowiem projekt Centrum Rekreacji dla Mieszkańców Osiedla Wielkopolska do XI edycji konkursu na zadania inwestycyjne zgłaszane przez jednostki pomocnicze Miasta Łodzi. Zgłoszenie zostało zweryfikowane pozytywnie i zatwierdzone do realizacji w 2017 roku. Przyznano na nie 674950 zł$^{18}$.

Projekt Centrum Rekreacji składa się z trzech części: siłowni zewnętrznej dla młodzieży, dorosłych i osób starszych, placu zabaw dla dzieci do lat czternastu oraz psiego parku. Centrum będzie zlokalizowane na niezagospodarowanym terenie zielonym pomiędzy ulicami: Żubardzką, Inowrocławską i al. Włókniarzy (ryc. 3).

${ }^{18}$ Zadania zatwierdzone do realizacji w 2017 roku w związku z zakończeniem XI edycji konkursu na zadania inwestycyjne zgłoszone przez jednostki pomocnicze Miasta Łodzi - osiedla, http://bip.uml.lodz.pl/_plik.php?id=44786 (dostęp: 25.06.2017). 


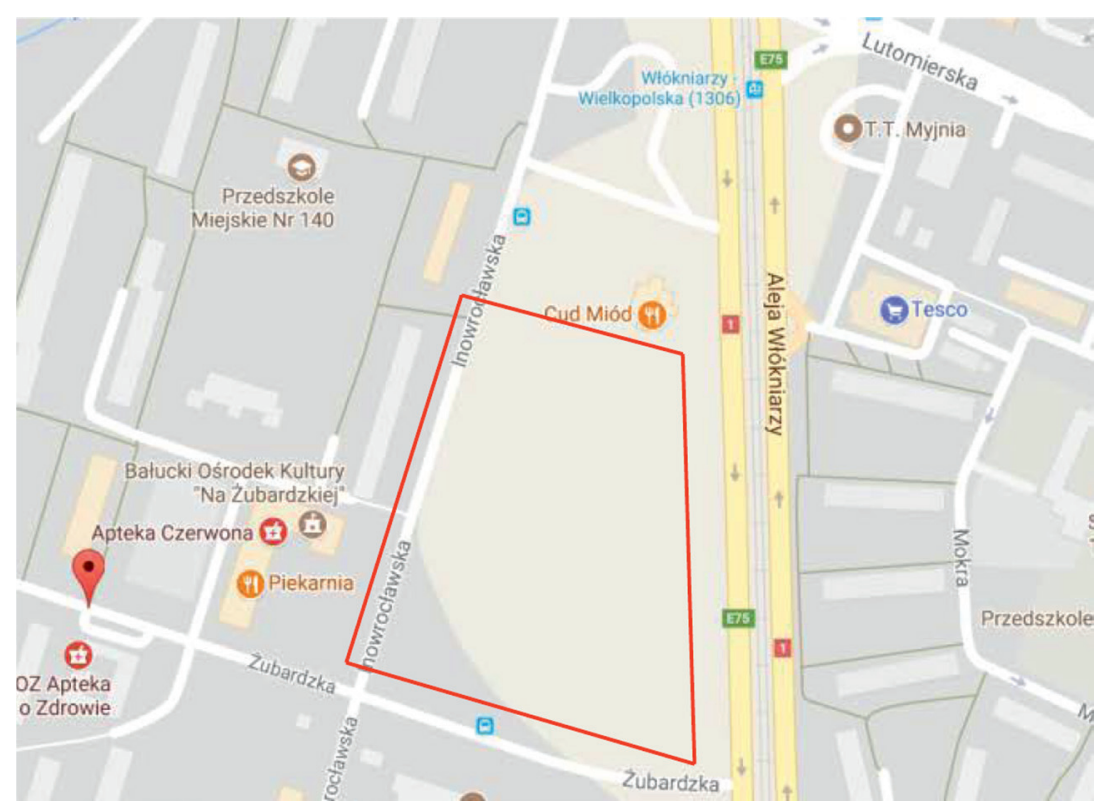

Ryc. 3. Lokalizacja Centrum Rekreacji dla Mieszkańców Osiedla Wielkopolska w Łodzi Źródło: opracowanie własne + podkład mapowy, https://www.google.pl/maps/place/Żubardzka, + Łódź/@51.7879742,19.4208502,17z/data=!4m5!3m4!1s0x471bcaa46cf8d6b 7:0x6720b36606e996c3!8m2!3d51.7869854!4d19.4163334 (dostęp: 25.06.2017)

Psi park będzie miał wyposażenie dostosowane do potrzeb psów i ich właścicieli. Teren będzie ogrodzony. Projekt urządzeń psiego parku ${ }^{19}$ (ryc. 4) zawiera m.in. tor przeszkód, wybieg, różne rodzaje pochylni. Nawierzchnia będzie dostosowana do wyposażenia. Dodatkowo w projekcie znalazły się: psia toaleta, kosze z podajnikami worków na odchody, hydranty i górka stanowiąca dodatkową przeszkodę dla psów. Przewiduje się stworzenie regulaminu korzystania z psiego parku oraz ustawienie tablic informacyjnych zawierających instrukcję obsługi wszystkich urządzeń w parku. Dopełnienie projektu będą stanowiły elementy małej architektury, takie jak: ławki, latarnie i kosze ${ }^{20}$. Korzystanie z kompleksu będzie bezpłatne. Celem głównym projektu jest integracja mieszkańców. Centrum rekreacji zostało zaprojektowane w taki sposób, by każda grupa wiekowa mogła z niego korzystać, a funkcje terenu będą od siebie oddzielone w celu zapewnienia komfortu i bezpieczeństwa różnym użytkownikom Centrum. Koniec budowy zaplanowano na rok 2018 (Rada Osiedla... b.d.).

\footnotetext{
${ }^{19}$ Rysunek urządzeń psiego parku w Projekcie budowlanym Centrum Rekreacji na Osiedlu Wielkopolska (dostęp: 02.02.2017).

${ }^{20}$ Projekt budowlany Centrum Rekreacji na Osiedlu Wielkopolska w Łodzi (dostęp: 02.02.2017).
} 


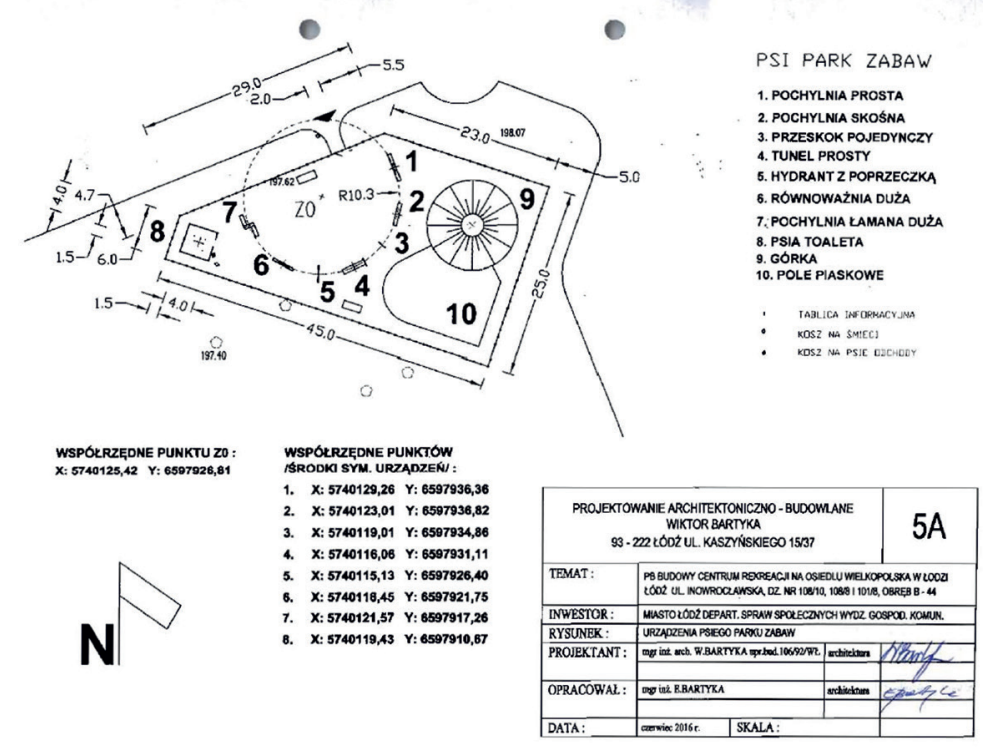

Ryc. 4. Rysunek urządzeń psiego parku zabaw

Źródło: Projekt budowlany Centrum Rekreacji na Osiedlu Wielkopolska w Łodzi (dostęp: 02.02.2017)

\section{Diagnoza - aspekt społeczny, właściciele psów}

Diagnozy dokonano na podstawie analizy ankiet pt. „Przestrzenie posiadaczy psów". Ankieta została przeprowadzona w dwóch terminach - w 2013 i 2015 r. Wzięło w niej udział 177 osób. Ze względu na brak możliwości precyzyjnego określenia populacji (operatu), próba miała charakter dostępnościowy. W badaniu wzięło udział 60\% mężczyzn, 36\% kobiet, a 4\% ankietowanych (7osób) nie określiło swojej płci. Średnia wieku wszystkich respondentów to 35 lat. Najliczniejszą grupę osób stanowiły kobiety do lat 24 (ok. 21\% wszystkich respondentów). Najmniej liczną grupę respondentów stanowili mężczyźni w kategorii wiekowej powyżej 65 lat - ok. 2\% ogółu respondentów. Dominowały osoby z wykształceniem średnim (58) i wyższym magisterskim (32). Ponad połowę stanowiły osoby czynne zawodowo. Uczniowie i studenci stanowili ok. 27\% respondentów, emeryci i renciści ok. 13,5\%. Postali nie pracowali.

Respondenci zapytani zostali o swój stosunek do zwierząt w ogóle. Najbardziej kontrowersyjne wśród stwierdzeń opisujących relacje z nimi okazało się to dotyczące posiadania przez zwierzęta duszy. Niewiele, bo połowa respondentów zgodziła lub zdecydowanie zgodziła się z tym. Odpowiedzi na inne pytania były dla psiarzy bardziej oczywiste - prawie każdy potwierdzał, że pies to najlepszy przyjaciel człowieka, że zwierzęta odczuwają ból tak jak ludzie, czy że pies to 
członek rodziny (tab. 3). Łódzkie wyniki są zasadniczo podobne co do kierunku do badań ogólnopolskich. W badaniu CBOS-u w 2003 roku odsetek twierdzących, że zwierzęta odczuwają ból wynosił 79\% (Postawy... 2003). Różnica procentowa może wynikać z faktu, że w Łodzi pytani byli posiadacze psów.

Tabela 3. Ogólny stosunek respondentów do zwierząt (tylko ważne odpowiedzi w \%)

\begin{tabular}{lcccccc} 
& \multicolumn{5}{c}{ Odpowiedzi respondentów } \\
\cline { 2 - 7 } $\begin{array}{l}\text { Opis relacji ze } \\
\text { zwierzętami }\end{array}$ & $\begin{array}{c}\text { zdecydo- } \\
\text {-wanie } \\
\text { zgadzam } \\
\text { się }\end{array}$ & $\begin{array}{c}\text { zgadzam } \\
\text { się }\end{array}$ & $\begin{array}{c}\text { ani zga- } \\
\text { dzam się } \\
\text { ani nie } \\
\text { zgadzam } \\
\text { się }\end{array}$ & $\begin{array}{c}\text { nie } \\
\text { zgadzam } \\
\text { się }\end{array}$ & $\begin{array}{c}\text { zdecydo- } \\
\text {-wanie } \\
\text { się nie } \\
\text { zgadzam }\end{array}$ & $\begin{array}{c}\text { trudno } \\
\text { powiedzieć }\end{array}$ \\
\hline $\begin{array}{l}\text { Pies to najlep- } \\
\text { szy przyjaciel } \\
\text { człowieka }\end{array}$ & 46,3 & 46,9 & 4,5 & 0,0 & 0,6 & 1,7 \\
\hline $\begin{array}{l}\text { Zwierzęta od- } \\
\text { czuwają ból tak } \\
\text { jak człowiek }\end{array}$ & 50,8 & 39,0 & 2,3 & 0,6 & 0,6 & 6,8 \\
\hline $\begin{array}{l}\text { Zwierzęta mają } \\
\text { duszę }\end{array}$ & 28,2 & 27,7 & 10,7 & 7,9 & 4,5 & 20,9 \\
\hline $\begin{array}{l}\text { Dzieci wycho- } \\
\text { wujące się ze } \\
\text { zwierzętami le- } \\
\text { piej się rozwijają }\end{array}$ & 32,4 & 48,3 & 6,8 & 0,6 & 0,0 & 11,9 \\
\hline $\begin{array}{l}\text { Mój pies jest } \\
\text { członkiem mojej } \\
\text { rodziny }\end{array}$ & 43,4 & 48,0 & 6,3 & 0,6 & 0,0 & 1,7 \\
\hline
\end{tabular}

Źródło: opracowanie własne

Ponieważ wiedza na temat posiadaczy psów i psów w Łodzi jest bardzo skromna, znaczna część ankiety poświęcona została na zebranie informacji faktograficznych, a nie opinii. Udało się dzięki temu ustalić przeciętną liczbę psów w gospodarstwie domowym. Wynosi ona 1,23. Oznacza to, że dominują gospodarstwa z jednym psem (80\%). Zalewie 6 badanych miało trzy psy - nikt nie podał większej liczby. Łódzkie psy miały średnio prawie 6,5 roku. Dominowały mieszańce. Następne w kolejności popularności były owczarki niemieckie i jamniki. Średnia podana waga psa wynosiła $17,5 \mathrm{~kg}$. Oznacza to, że dominują psy średniej wielkości. Należy jednak po pierwsze pamiętać o znacznym rozproszeniu wartości wagi - od 1 do $85 \mathrm{~kg}$, po drugie, o jak się wydaje, słabej w tym zakresie wiedzy właścicieli. 
Kolejne pytanie dotyczyło sposobu w jaki ankietowani stali się właścicielami psów. Najwięcej osób pozyskało psa z hodowli lub dostało od znajomych. Najmniej osób otrzymało psa w prezencie. Jedynie 20 osób adoptowało psy ze schroniska (ryc. 5).

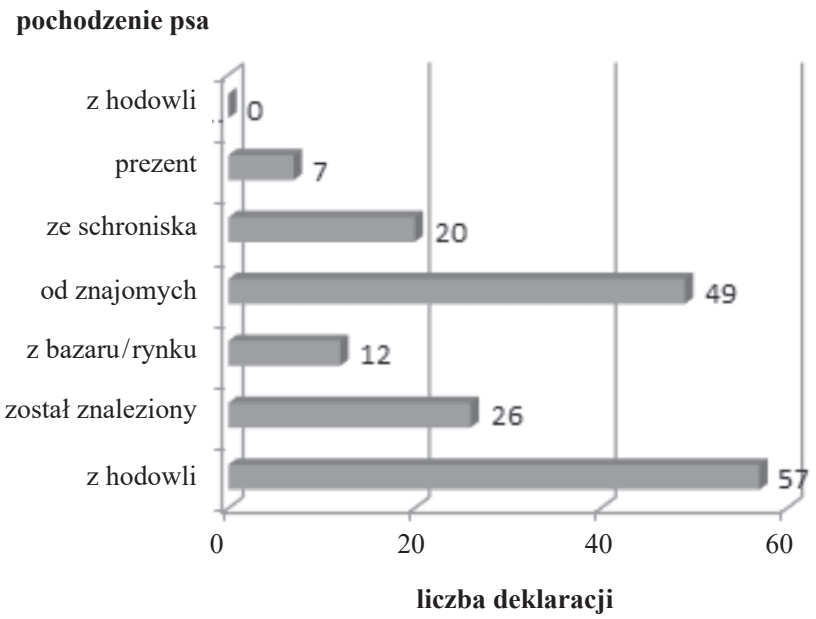

Ryc. 5. Pochodzenie psów respondentów

Źródło: opracowanie własne

Psy były kupowane przede wszystkim, by stać się towarzyszami człowieka („dla towarzystwa”). W dalszej kolejności miały prowokować do spacerów i być towarzyszami zabaw dla dzieci. Okazało się, że stosunkowo mało osób kupowało psa z myślą o jego użytkowości - stróżowaniu bądź założeniu hodowli. Zapytani o obecną rolę psa w domu, respondenci najczęściej podawali „towarzystwo” (75\%), na drugim miejscu wymieniając rekreację (12\%), czyli spacery. Nawet Ci, którzy nabyli psa z myślą o wykorzystaniu go do uprawiania sportu lub ochrony domu mieli psa, w chwili badania, głównie do towarzystwa.

Stosunek respondentów do pupili wydaje się być bardzo zdroworozsądkowy. Ponad $80 \%$ badanych powiedziało, że pies jest dla nich „bardzo ważny, ale choć staram się o niego dbać, nie podporządkowuję mu całego życia” (tab. 4).

Trudno stwierdzić czy stosunek do psa przekłada się pozytywnie na czas mu poświęcony. Respondenci deklarowali bowiem, że przeciętnie poświęcają pupilom ok. $90 \mathrm{~min}$ w tygodniu i ponad $120 \mathrm{~min}$ w dni wolne od pracy. Czas ten wypełniony jest głównie spacerami. W tym przypadku przeciętna w tygodniu wynosi $20 \mathrm{~min}$, w weekend $40 \mathrm{~min}$, dominanta to jednak odpowiednio $10 \mathrm{~min}$ i $30 \mathrm{~min}$ (tab. 5). W 2013 roku oznaczało to, że tyle samo czasu poświęcono psu i internetowi (por. Badanie... 2013). 
Tabela 4. Znaczenie psa w życiu respondentów

\begin{tabular}{lccc}
\multicolumn{1}{c}{ Pies jest dla mnie... } & Częstość & Procent & Procent ważnych \\
\hline $\begin{array}{l}\text { Najważniejszy i jemu podpo- } \\
\text { rządkowuję całe swoje życie }\end{array}$ & 13 & 7,3 & 7,5 \\
\hline $\begin{array}{l}\text { Bardzo ważny, ale choć staram } \\
\text { się o niego dbać, nie podpo- } \\
\text { rządkowuję mu całego życia }\end{array}$ & 146 & 82,5 & 83,9 \\
\hline Nieważny, ale dbam o niego & 13 & 7,3 & 7,5 \\
\hline W ogóle nieważny & 2 & 1,1 & 1,1 \\
\hline Ogółem & 174 & 98,3 & 100,0 \\
\hline Brak odpowiedzi & 3 & 1,7 & - \\
\hline Suma & 177 & 100,0 & - \\
\hline
\end{tabular}

Źródło: opracowanie własne

Tabela 5. Czas poświęcony psu (w minutach)

\begin{tabular}{lccc}
\multicolumn{1}{c}{ Wyszczególnienie } & Średnia & Mediana & Dominanta \\
\hline $\begin{array}{l}\text { Ile czasu poświęca psu } \\
\text { W ciągu dnia w tygodniu } \\
\text { pracy }\end{array}$ & 93,3 & 60,0 & 60,0 \\
\hline $\begin{array}{l}\text { Przeciętnie ile czasu } \\
\text { poświęca psu w ciągu dnia } \\
\text { wolnego od pracy }\end{array}$ & 126,9 & 120,0 & 120,0 \\
$\begin{array}{l}\text { Ile razy dziennie wychodzi } \\
\text { z psem na spacer }\end{array}$ & 2,7 & 3,0 & 3,0 \\
\hline $\begin{array}{l}\text { Przeciętny spacer } \\
\text { w tygodniu }\end{array}$ & 22,0 & 15,0 & 10,0 \\
\hline $\begin{array}{l}\text { Długi spacer w tygodniu } \\
\text { Przeciętny spacer } \\
\text { w weekend }\end{array}$ & 40,4 & 30,0 & 30,0 \\
\hline Długi spacer w weekend & 37,7 & 30,0 & 30,0 \\
\hline
\end{tabular}

Źródło: opracowanie własne

W ankiecie zaproponowano także blok pytań dotyczących użytkowania przestrzeni publicznych (ryc. 6). W pierwszym pytaniu poproszono o wskazanie miejsc codziennych spacerów. Okazało się, że najwięcej osób wychodzi ze swoimi pupilami tylko przed dom (blok) lub na najbliżej zlokalizowany skwer, rzadziej do 
parku nieopodal miejsca zamieszkania. Jedynie 13 osób ze wszystkich odpowiadających wychodzi z psami w miejsca oddalone od domu. Świadczy to o dużej eksploatacji terenów zieleni osiedlowej. Respondenci wybierają tereny zlokalizowane najbliższej miejsca zamieszkania, by oszczędzić swój czas.

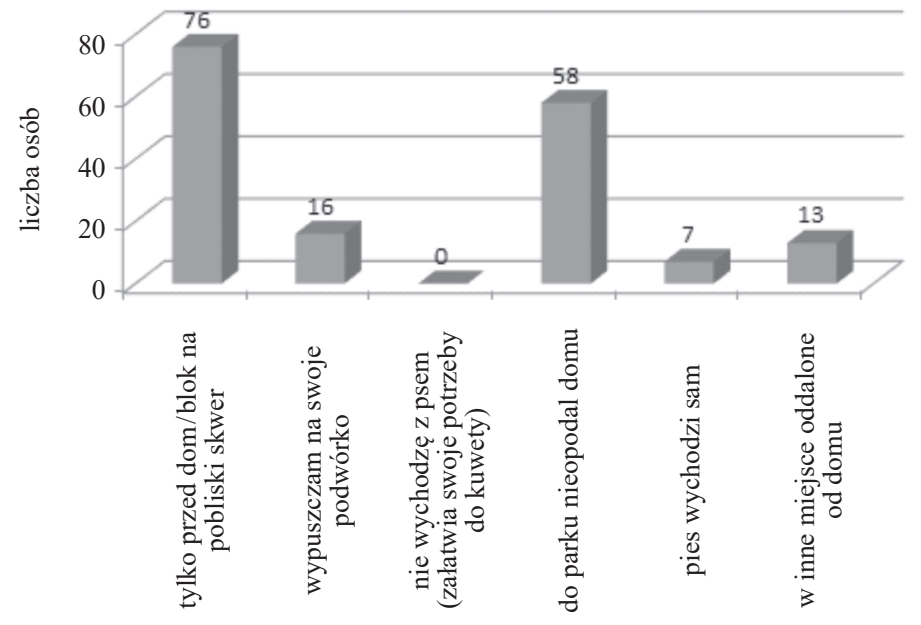

Ryc. 6. Najczęściej wybierane miejsca spacerów z psami Źródło: opracowanie własne

Następne dwa pytania odnosiły się do terenów, gdzie można swobodnie „wybiegać” psa w Łodzi oraz do szczególnych miejsc spotkań „psiarzy” na terenie miasta. Respondenci wybierając miejsce do „wybiegania” psa najczęściej polecali: Las Łagiewnicki (20 wskazań), Park Podolski (11 wskazań), Park im. J. Piłsudskiego (potocznie zwany Zdrowie - 8 wskazań), Park Helenów (7 wskazań), Park 3. Maja (5 wskazań) i Park im. J. Poniatowskiego (4 wskazania). Osiemnaście osób nie potrafiło podać takiego miejsca. Odpowiedzi respondentów wskazują na to, iż wybierają oni parki o stosunkowo dużej powierzchni, gdzie można swobodnie zwolnić psa ze smyczy. Warto podkreślić, że wymieniane miejsca rozproszone były na terenie całego miasta.

Jeśli chodzi o wskazanie szczególnych miejsc spotkań „psiarzy”, aż 130 respondentów stwierdziło, że nie ma takich miejsc w Łodzi. Dalsze 5 osób zaznaczyło odpowiedź „trudno powiedzieć”. Nieliczni wymieniali: Park Podolski i Park im. J. Piłsudskiego na Zdrowiu - po 4 wskazania. Respondenci wymieniali pojedynczo także obszar Bałut, Park Helenów, Park im. Mickiewicza, Park im. J. Matejki i obszar przy ul. Konstantynowskiej (wjazd od Retkini).

Czy zatem Łódź to dobre miejsce dla psów? Większość ankietowanych (45\%) stwierdziło, że Łódź nie jest ani dobrym ani złym miejscem dla czworonogów. Prawie co trzeci respondent miał trudności z odpowiedzią na zadane pytanie. 
Jedynie 13\% osób uważało, że Łódź jest dobrym miejscem dla posiadaczy psów. $\mathrm{Z}$ drugiej strony miasto zostało ocenione negatywnie tylko przez co dziewiątego właściciela psa (ryc. 7).

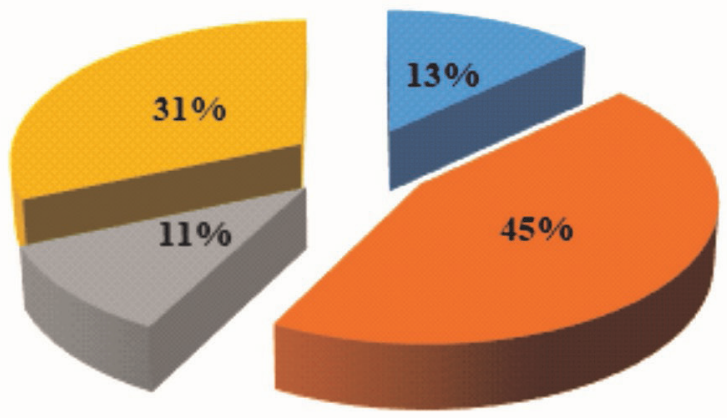

- jest dobrym miejscem

jest ani dobrym ani złym

miejscem

jest złym miejscem

trudno powiedzieć

Ryc. 7. Stosunek ankietowanych do Łodzi jako miejsca dla posiadaczy psów

Źródło: opracowanie własne

Konsekwentnie zapytano o zmiany jakie należałoby wprowadzić, by mieszkanie w Łodzi z psem było łatwiejsze. Okazało się, że największe znaczenie dla respondentów miało wyznaczenie na terenie miasta obszarów przeznaczonych dla psów (tab. 6).

Tabela 6. Działania jakie należałoby podjąć, by Łódź stała się miejscem przyjaznym dla posiadaczy psów

\begin{tabular}{lc}
\hline \multicolumn{1}{c}{ Co należałoby zmienić w Łodzi? } & \% odpowiedzi \\
\hline Nic, to miasto przyjazne dla „psiarzy” & 6,4 \\
\hline Wyznaczyć tereny przeznaczone dla psów (np. w parkach) & 68,9 \\
\hline Udostępnić miejsca publiczne (np. sklepy, restauracje) & 14,2 \\
\hline Inne & 2,8 \\
\hline Trudno powiedzieć & 19,8 \\
\hline
\end{tabular}

Źródło: opracowanie własne

Bardzo szczególnym miejscem związanym z psami jest cmentarz dla zwierząt. W Łodzi od wielu lat funkcjonuje takie miejsce. Cmentarz zlokalizowany jest przy ul. Malowniczej. Około 30\% ankietowanych uważa, że jest on (cmentarz dla zwierząt) potrzebny na terenie Łodzi. $Z$ kolei ok. $25 \%$ respondentów nie jest przeciwnego zdania, a ok. $20 \%$ badanych ma ambiwalentny stosunek do tego stwierdzenia (ryc. 8). 


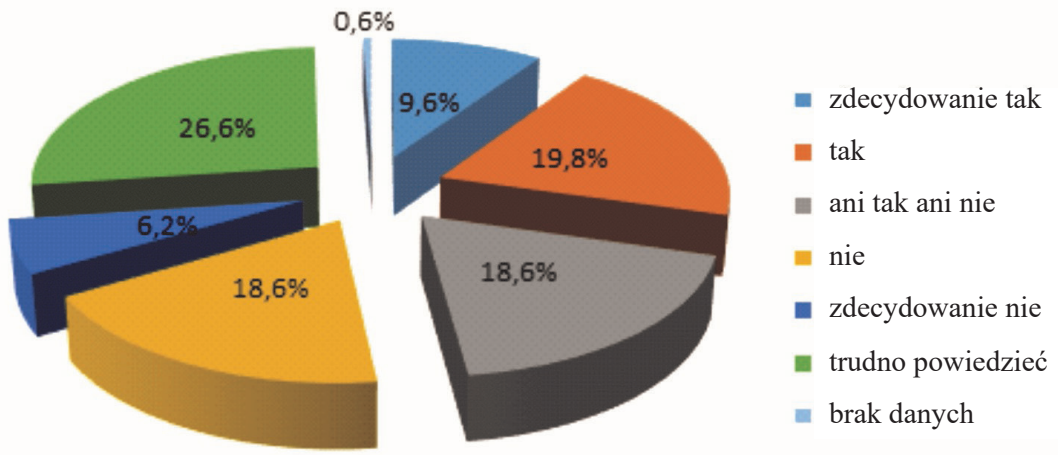

Ryc. 8. Czy w Łodzi potrzeby jest cmentarz dla zwierząt?

Źródło: opracowanie własne

\section{Podsumowanie}

Celem artykułu było przedstawienie wybranych przestrzennych konsekwencji posiadania psów w mieście. Jak dowiedziono, zjawisko ma relatywnie dużą skalę - liczbę psów w Łodzi ocenia się nawet na 80 tys. Dla swoich właścicieli są ważnymi towarzyszami życia. Każdego dnia „odpowiadają” za organizację prawie dwóch godzin z czasu wolnego domowników. Dzięki nim blisko $2 / 3$ właścicieli poszerzyło krąg znajomych.

Działania władz samorządowych w zasadzie ograniczają się do realizacji zapisów prawnych i kończą na zapewnieniu porządku w mieście. Oznacza to działania na rzecz psów bezdomnych oraz zapobieganie bezdomności. Ostatnie z działań polega głównie na dofinansowaniu sterylizacji i chipowania.

Na pewno jednak najbardziej znaną akcją władz miasta jest „Posprzątaj! To nie jest kupa roboty". Łodzianie są w niej namawiani do sprzątania po swoich psach. Akcja wydaje się przynosić efekty, szczególnie że wspierana jest przez Straż Miejską. Dane z tej instytucji wskazują na spadek w ciągu ostatnich pięciu lat wszelkich wykroczeń związanych z posiadaniem psów (głównie czystość i bezpieczeństwo). Czy jednak oznacza to podniesienie poziomu czystości w mieście? Chyba raczej dostosowanie się do przepisów. Skoro mandat najczęściej wystawia się za brak sprzętu do posprzątania, a nie za faktyczne pozostawianie nieczystości, to sprzątanie się nie liczy, lecz posiadanie torebki na odchody. Konflikt między niesprzątającymi po psach właścicielami a innymi łodzianami trwa.

Niestety, do końca 2017 roku w Łodzi nie było żadnego specjalnie wyznaczonego dla psów parku czy też innej przestrzeni. Jedyna podjęta w ostatnich latach próba budowy takiego miejsca zakończyła się fiaskiem - a dokładnie dewastacją 
obiektu. Z inicjatywy jednej z rad osiedla w ramach większego kompleksu rekreacyjnego powstać ma niewielki „psi park”. Zakończenie budowy przewiduje się w 2018 roku. Osiągnięcia władz miasta w zakresie dostosowania przestrzeni publicznych do potrzeb psów i ich właścicieli polegają przede wszystkim na wystawieniu specjalnych koszy na odchody. Jak wykazała jednak inwentaryzacja terenowa ich liczba jest mała.

Brak aktywności samorządowców w tworzeniu miejsc przyjaznych psom przełożył się na oceny właścicieli czworonogów. Niewiele osób uważało, że Łódź to miasto dobre dla psów i „psiarzy”. Podstawowy zgłaszany problem to wyznaczenie miejsc, gdzie swobodnie z psami można chodzić na spacery. Wziąwszy pod uwagę, że respondenci w większości czas z psami spędzali w niewielkiej odległości od domów, takich miejsc brakuje głównie na dużych osiedlach mieszkaniowych. Jak się wydaje nie chodzi o wielkie wybiegi, a raczej o wygrodzone części istniejących parków lub trawniki, na których utrzymanie porządku i czystości byłoby łatwe. Jednocześnie nie dochodziłoby do konfliktów między posiadaczami psów a innymi osobami.

Podobne rozwiązania istnieją już w innych miastach. Choćby w Warszawie znajdują się cztery takie miejsca. Większość została zrealizowana w ramach budżetów obywatelskich. Ich powstanie i istnienie zależy od kultury posiadania i nieposiadania psów.

\section{Bibliography}

Badanie budżetu czasu ludności w 2013 r., GUS, https://stat.gov.pl/files/gfx/portalinformacyjny/pl/defaultaktualnosci/5486/18/1/1/notatka_bc_2013_22_08_ost_2_.pdf.

Duricek M., Obodyński K., 2006, Syntetyczne podstawy rekreacji i turystyki, Wydawnictwo Uniwersytetu Rzeszowskiego, Rzeszów.

Durkheim E., 2011, Samobójstwo, Oficyna Naukowa, Warszawa.

Konecki K., 2005, Ludzie i ich zwierzęta. Interakcjonistyczno-symboliczna analiza spotecznego świata wlaścicieli zwierzą domowych, Wydawnictwo Scholar, Warszawa.

Lorenz K., 2013, I tak człowiek trafit na psa, Grupa wydawnicza Foksal sp. z o.o., Warszawa.

Postawy wobec zwierzat, 2003, BS/79/2013, CBOS, http://www.cbos.pl/SPISKOM.POL/ 2013/K_079_13.PDF

Rada Osiedla Teofilów-Wielkopolska, b.d.

Rozporzadzenie Ministra Spraw Wewnętrznych i Administracji z dnia 26 sierpnia 1998 roku w sprawie zasad $i$ warunków wyłapywania bezdomnych zwierząt (Dz.U., 1998, nr 116, poz. 753 , z późn. zm.).

Rozporzadzenie Ministra Spraw Wewnętrznych i Administracji z dnia 28 kwietnia 2003 roku w sprawie wykazu psów uznawanych za agresywne (Dz.U., 2003, nr 77, poz. 687).

Sławek M., Śleboda R., Bajorek W., Rzepko M., Nowak A., 2011, Przestrzeń rekreacyjna aktywności ruchowej $w$ calorocznych zamkniętych obiektach sportowo-rekreacyjnych na podstawie wybranych jednostek osiedlowych Łodzi, „Ekonomiczne Problemy Usług", 79: 275-301. 
Szacki J., 1964, Durkheim, Wydawnictwo Wiedza Powszechna, Warszawa.

Szkwarek M., 2016, Miasta, które nadal pobieraja opłatę za psa, Bankier.pl, https://www. bankier.pl/wiadomosc/Miasta-ktore-nadal-pobieraja-oplate-za-psa-7421102.html.

Toczek-Werner S., 2007, Podstawy rekreacji i turystyki, Wydawnictwo AWF Wrocław, Wrocław.

Uchwała Nr XXXI/808/16 Rady Miejskiej w Lodzi z dnia 15 czerwca 2016 roku w sprawie wprowadzenia Regulaminu utrzymania czystości i porządku na terenie miasta Łodzi (Rozdział 5 § 19.2).

Uchwała nr XLIII/1154/17 Rady Miejskiej w Łodzi z dnia 15 marca 2017 roku w sprawie przyjęcia „Programu opieki nad zwierzętami bezdomnymi oraz zapobiegania bezdomności zwierząt w Łodzi na rok 2017”.

Ustawa z dnia 12 stycznia 1991 roku o podatkach $i$ opłatach lokalnych (Dz.U., 2006, 121.844).

Ustawa z dnia 13 września 1996 roku o utrzymaniu czystości i porządku w gminach (Dz.U., 1996, nr 132, poz. 622).

Ustawa z dnia 21 sierpnia 1997 roku o ochronie zwierząt (Dz.U., 2003, nr 106, poz. 1002, z późn. zm.).

Ustawa z dnia 11 marca 2004 roku o ochronie zdrowia zwierząt oraz zwalczaniu chorób zakaźnych zwierząt (Dz.U., 2008, nr 213, poz. 1342, z późn. zm.).

Verginelli F., Capelli C., Coia V., Musiani M., Falchetti M., Ottini L., Palmirotta R., Tagliacozzo A., De Grossi Mazzorin I., Mariani-Costantini R., 2005, Mitochondrial DNA from Prehistoric Canids Highlights Relationships between Dogs and South-East European Wolves, „Molecular Biology and Evolution”, 22(12), 1 December 2005: 2541-2551, https://doi.org/10.1093/molbev/msi248.

\title{
LIFE WITH DOGS IN THE CITY
}

\begin{abstract}
The city is by its definition a space appropriated by culture, it is artificial and anthropogenic environment, the place of residence of people. The numbers, however, are significant. In the United States, the number of households with dogs exceeds the number of households with children. In 2016 there were over 60 million (the number of dogs is estimated at 70 million) of households with a dog. The value of the market of products related to the maintenance of domestic pets was estimated in 2017 at approx. USD 70 billion. It means almost $60 \mathrm{pp}$. growth over the past 10 years. The average dog owner assessed his annual expenses for about 1,600 USD. The largest part was devoted to veterinary care and hotels for animals. It is also worth mentioning the ever-growing animal insurance market.

In addition to the importance for the economy, having dogs has other consequences. First of all, you can point out their social role here. Dogs and other pets have become „family members” and ,best friends”. One can risk the thesis that they are, in some cases, a substitute for partners or children - at least some of the owners treat them as such.

The aim of the article is to indicate the selected spatial consequences of having dogs in the city. The diagnosis covers both the elements of real space as well as the social perception of the phenomenon of having and housing dogs in the city. What is spatial is primarily related to public space, recreation and leisure. The case study is Łódź, a city of 700,000 residents and 80,000 dogs (estimates). The research was carried out from 2013
\end{abstract}


to 2017. An inventory was made of selected green areas in Łódź and expert interviews with representatives of the Municipal Police in Łódź and the Department for Economic and Control Affairs of the Department of Municipal Economy in Łódź. In addition, data obtained from institutions such as: Municipal Police in Łódź, Poviat Veterinary Inspectorate (PIW) in Łódź and the Local Data Bank of the Central Statistical Office were analyzed. Self-administrative interviews with dogs' owners were conducted as well. The focus was on the current situation, which in practice means the last five years.

Keywords: City space, dogs, dogs' owners, use of public spaces, local government.

Dr hab. Ewa Klima, prof. nadzw. PŁ Zakład Gospodarki Przestrzennej i Geomatyki Wydział Budownictwa, Architektury i Inżynierii Środowiska Politechnika Łódzka e-mail: ewa.klima@p.lodz.pl

Inż. Diana Stasiak Kolegium Gospodarki Przestrzennej Politechnika Łódzka e-mail: diana.maria.stasiak@gmail.com 